\title{
"Till we hear the last all clear": gender and the presentation of self in young girls' writing about the bombing of Hull during the Second World War.
}

On the 9 February 1942 Peggy Warren, a teacher at Springburn Street School in Hull, set her class of ten to twelve-year-old girls the task of producing an essay entitled, 'What Happened to Me and What I Did in the Air Raids.' ${ }^{1}$ Springburn Street School was a mixed school of around 900 pupils, situated amongst the heavily-bombed working-class terraces north of Hull's docks. ${ }^{2}$ The essays thus evidence a vivid familiarity with the death and destruction caused by the sporadic, but heavy bombing experienced by Hull in over 60 air raids between 1940 and $1945 .^{3}$ The school had already absorbed a number of the children from local bombed-out schools when, shortly after the essays were composed, it was destroyed itself. ${ }^{4}$ 60 years later, the collection of 29 manuscripts was presented to Hull Local Studies Library archive by Miss Warren's nephew and survives as a snapshot of young girls' experiences during an extraordinary period for British civilians. The essays — produced on a single day in response to a specified question - evidence how young girls made sense of their experience of bombing. The selfhoods produced through the girls narratives were shaped by gendered discourses on civilian service and, as such, provide a rare opportunity to investigate the constitution of wartime subjectivities among young girls living through 'the blitz'.

This article uses the essays as a case study to engage with two areas of discussion in the existing research on the use of children's writing and notions of gender during the Second World War. First, it examines the composition of the essays to understand the role of young girls as writers in mid-twentieth century Britain, asking how conditions created by genre and the question set served to both constrain and empower individuals in the production of texts. The section than explores how the girls' accounts attempt to create calm, balanced selves in response to expressions of fear, anxiety and terror. The recounting of traumatic experiences is repeatedly countered by the language of quiet defiance, expressed within a framework of 
civilian service and national endeavour. The article thus considers how the practice of narrating recent events through the selection of various discursive elements might be interpreted as an act of 'composure' to challenge a priori judgements about the value of children's writing to the study of the past. $^{5}$

A considerable amount of historical investigation has dealt with children's experience of the Second World War, yet there exists a tension over the use of young children's writing alongside that produced by adults or older children. ${ }^{6}$ Psychologist Susan Issacs made use of children's essays about evacuation from London to Cambridge to understand their experiences in 1941 and recent work by John Welshman has also used children's writing to examine evacuee experiences. ${ }^{7}$ However, there has yet been no detailed examination of children's contemporary writing to understand how subjectivities concerning gender might be influenced by dominant wartime discourses and the effects of bombing. Where written and oral testimony has been employed to understand the experience of aerial bombardment, preteens' writings have remained largely unused. ${ }^{8}$ Amy Helen Bell used personal testimony to understand the experience of the London Blitz, but found the accounts of children younger than 13 were 'for the most part psychologically and historically un-illuminating records of times and durations of raids and daily activities. ${ }^{9}$ This article, however, argues that younger children's accounts, like adults', represent an on-going dialogue between lived experience and contemporary modes of understanding and articulating that experience. Thus, whilst some of the girls' writings studied here do not realise certain aesthetic standards of narrative prose in the same way that some adults do, this does not negate the narratives' status as a record of experiences, the form of which is conditioned by available conceptual schemes and discursive technologies.

The second and third sections of this article examine the formation of the texts to reveal the centrality of wartime gender roles to the depiction of civilian service against the 
backdrop of the home. Valerie Walkerdine and Penny Tinkler have both stressed how notions of twentieth century girlhood were constructed through negotiations between popular culture and a variety of discourses of femininity. ${ }^{10}$ The accounts studied here evidence Walkerdine's assertion that the girls themselves moulded specific girlhoods in relation to various conditions, in this case discourses of home defence and collective national endeavour. The essays contain visions of a world under stress and, whilst the handling of fear seems crucial to achieving a sense of composure, the presentation of mothers and fathers appears to have played an equally important role. Fathers and other male relatives are frequently depicted defending homes from external threats, whilst mothers — in many cases assisted by the girls themselves - appear as the maintainers of the internal order of the home. In the essays the home thus functions as a 'first world' that forms a locus for experience, through the defence of which the girls were able to represent their families' contribution to the war effort in line with models emanating from the state. ${ }^{11}$ The article thus builds upon work by Penny Summerfield and Corinna Peniston-Bird, which has noted that state-produced constructs of wartime civilian service often involved attaching distinctly gendered understandings to women's role within the home. ${ }^{12}$ By seeking to understand how expectations of civilian service were given meaning with reference to the protection and maintenance of the home, the article thus also intervenes in debates surrounding the impact of the war in the construction of gendered identities in the post-war period. ${ }^{13}$

\section{The Girl as Writer}

This first section attempts to understand how the historian might approach a collection of essays which evidence a great deal of variation in style, length, and syntactical fluency. Some of the essays, for example, use direct speech, others indirect speech, whilst many are simple narratives composed in the first person, creating issues in comparing the girls' voices. The 
length of each essay varies between as few as 100 words to as many as 700 and, on occasion, poor standards of expression and handwriting make the texts difficult to decipher. Pam Alldred and Erica Burman have claimed that in applying techniques of discursive analysis to children's accounts there exists a tendency to oscillate between two extremes founded on essentialist judgements about the nature of children's writing. Scholars have either attributed authenticity to children's writing based on romanticised discourses of childhood, or, conversely, dismissed their words in favour of the supposed educated and civilised rationality of some adults. ${ }^{14}$ Christina Benninghaus, in her analysis of teenage girls' essays produced in Weimar Germany, is one of several authors who point towards a method by which we might begin to understand and use children's writing, despite the manifest challenges posed by using such varied material. The essays she studies, produced in schools at the behest of sociologists, suggest that the girls' narratives harnessed a series of constructs selected from the dominant discourses available to them, which were informed by the disciplinary conditions of composing in the prescribed genre. ${ }^{15}$

Carolyn Steedman's The Tidy House - which explores the creative writing process amongst a trio of eight-year-old girls - also provides a method to tackle the variability found in the essays studied here. Amongst Steedman's conclusions is the repudiation of the idea that we can access an 'authentic' voice of the child any more than adult writing provides a window onto 'authenticity'. ${ }^{16}$ As a result, Steedman's approach, which views written work as the product of utilising various accessible discursive elements, does not rely on the ability of children to articulate themselves at a predetermined level. The only condition imposed is that the text can be read in the most functional of senses. Steedman's conclusions thus open up the possibility of interrogating and drawing conclusions about the discursive landscape in which the essays studied here were produced. 
Fundamental to Benninghaus' and Steedman's arguments is the effect of genre and the question upon the production of the texts they study. ${ }^{17}$ Authors in the field of discourse analysis have also highlighted that genre plays a crucial role in structuring potential responses in written and spoken communications. ${ }^{18}$ The genre of the school essay here dictates certain parameters which must be observed by the pupil, including content, format and adherence to the prescribed question. In a similar manner, the question also locates the respondent within a particular set of potential responses. The girls studied here were asked to recount: "What happened to me...' requiring a description of events, but also: ' .... and what I did...' requiring them to situate themselves within an active role in their accounts. The generic framework of the exercise and the position created by the question confines the possible responses, but also affords the opportunity to construct a useful, conformative picture of the girls' and their families' roles as active citizens during the Hull Blitz.

There is, sadly, no record of what Miss Warren told the class in addition to the initial question or what guidance she may have offered concerning content. It is possible that the girls were given a model answer, or presented with a list of elements they might discuss. Indeed, mothers and fathers, shelter use, expressions of fear and depictions of damaged homes appear in many of the accounts. Whether these common features appear by dint of instruction from Miss Warren or due to the salience of these elements in the girls' lives, is unknowable. Nevertheless, understanding a little about the background to the essays allows for some productive speculation. Although no indication is given in the text, it is almost certain that the essays were produced as part of the operational research project known as 'The Hull and Birmingham Survey' for the wartime government. ${ }^{19}$ This survey asked the exact question evidenced in the girls essays to hundreds of school children in the two cities in order to understand the impact of German bombing on civilian morale and daily life. 
Combining speculation over the formation of the question with the background to the government study allows us to view the girls' writing as part of a wider discursive practice through which the idea of the wartime civilian was being produced and reinforced. The question asked constructs two different spaces from which to speak: the subject as a passive object to whom things happen and the subject as active agent who does things in and to the world. As such the question's syntactical structure appears to be closely related to the assumptions and aims orchestrating the discourse of which it is a part. On this reading, the question is a surveillance technology which, by inducing children to speak, worked to solidify a particular form of knowledge about the effects of bombing. The figure of the demoralised or fortitudinous civilian appears at the centre of this discourse and the question's syntax exemplifies the terms within which experts imagined, and attempted to bring into being, the figure of the wartime civilian.

There is no indication whether the children were aware that they were assisting with a government study, and the survival of the documents in Hull's archives suggests that Miss Warren may not have submitted the essays to the survey. There is however some evidence that she offered certain guidance, which suggests how said guidance might be reproduced in the text. Several of the children articulate 'the difference' that the air raids made to their lives and homes. Nancy Nunn, for example, ends her recollection with the phrase 'it [the bombing] has made my nerves terrible and it has made a lot of difference to me' ${ }^{20}$ The phrase appears rather suddenly and seems to come as something of an afterthought as does Hilda Chalk's comment that 'it made a lot of difference to the homes of poor people who could not buy any furniture. Well we will see it through and we will have to buy new furniture now but still our homes are still different. ${ }^{21}$ It is possible that the instructions given to Miss Warren stipulated that the essays should deal with how the bombing had changed lives — had made a 
difference - and, as such, the appearance of the idea of difference may point to anxieties in central government concerning civilian morale.

Speculation regarding the potential readership further opens up the motivations behind the girls' presentation of the self in the essays and here the notion of 'composure', outlined by historians such as Graham Dawson and Penny Summerfield is useful. ${ }^{22}$ 'Composure', as outlined by Dawson has a dual meaning. On one hand 'composure' merely refers to the act of composition; however, Dawson also argues that telling life stores involves constructing oneself as a subject possessed of 'composure — integration of different parts of the self to produce a sense of order and completeness - to achieve a state of personal balance and emotional security. Life stories like those in the girls' essays are not told in isolation, and as Dawson acknowledges 'the effort towards composure is an inescapably social process. Stories are always told to an audience, actual or imagined, from which different kinds of response are elicited. ${ }^{23}$

The primary recipient here was the teacher, but work may also have been read out in class making it likely that the girls may have attempted to promote a favourable image of themselves and their families to peers as well. The classroom is, of course, not a hermetically sealed environment, and the potential for leakage provides further possibilities for the children's sentiments to be disseminated into the wider community. The possibility that the girls may have been told that the essays were to be used in government research would likely only have heightened the importance to the girls of presenting calm and useful images of their families and themselves. Against powerful and pervasive messages emanating from the state on a spectrum of topics including morale, civilian service, rationing, shelter use and the blackout, the girls rarely transgress ideas of correct behaviour during raids or civilian fortitude after them. 
The girls' essays demonstrate their attempts to present composed and fortitudinous selves within popular discourses of morale and hint at an imagined intersubjectivitive relationship with a reader in a position to judge the girls' contribution to the war effort. Historians like Robert MacKay and Arthur Marwick have shown how the language of maintaining morale dominated government concerns, especially prior to $1943 .{ }^{24}$ The prevailing attitude by 1941 was that good morale was not just characterised by a determination to carry on, but also by 'cheerfulness, support for leaders, belief in ultimate victory', and behaviours such as 'cooperativeness and neighbourliness, high productivity, low absenteeism and volunteering'. ${ }^{25}$ Adherence to these government concepts of active morale is frequently in evidence in the essays, yet these co-exist with expressions of fear and terror. Winifred Stubbins recalls people fainting, screaming and crying, while she herself lay on the floor and prayed for help until the air raid was over. ${ }^{26}$ There is little reticence to articulate this type of fear amongst the girls and all but a few mention being frightened, having bad nerves or feeling some aspect of terror. Sheila Stothard recalls that "we thought every minute was our last' and paints a bleak picture of the psychological trauma experienced by the population:

I do know everyone was afraid to stop in the town at night. They used to run away anywhere to get away from the town of Hull, even if it was to sleep in an open field they were so frightened. I was one of those who went out to sleep. ${ }^{27}$

Yet, she finishes on an optimistic note adding: 'although Hull has gone through some awful, terrifying raids, we will always keep our spirit up and keep smiling'. ${ }^{28}$ Repetition of 'we' and 'our' — the shifting of the first person voice into collective voice — implies a blending or a dissolution of personal selfhood into the communal. This may indicate an articulation of collective belonging, or it may be a distinctive attempt to manage fear through the idealisation of the collective spirit via the sublimation of anxieties into the national myth. The repetition of this shift from the 'I' to the 'we' in multiple accounts in response to moments of 
danger appears to indicate that the girls as narrators were susceptible to the state's attempts to inculcate a sense of collective solidarity.

Lyndsey Stonebridge points out that by 1942 psychoanalysts were arguing that the 'Mass-Neurosis Myth' — the myth that air-raids would give rise to wide-spread war neurosis — had been replaced with a 'No-Neurosis Myth'. ${ }^{29}$ In 1942 a psychiatrist wrote to the Daily Herald with the following story:

I have met many conscientious citizens who are afraid of being afraid...I tell them it is natural to feel fear in the air raids and human to show fear. And it is honest to admit it. What your country has a right to ask of you is that you don't cause panic amongst others...Courage consists in admitting fear and controlling it for the sense of duty and to strengthen others. ${ }^{30}$

In the essays there is little sense that the girls were afraid of fear, rather an understanding that whilst feeling it during a raid was natural, the contribution expected of them was to carry on as best they could. The habit of articulating a final defiant line in the essays appears to function as a common means of achieving balance, both in the presentation of self and as part of the material act of composition itself. Hilda Chalk, despite describing being terrified and feeling physically ill, states that ' $I$ felt too sick and ill to do anything, it made a lot of difference to our home and many others were destroyed. But we still keep smiling [my emphasis]' and a similar phrase appears as Nancy Nunn's counterpoint to her frayed 'nerves': 'we still keep smiling through and try to forget those dreary nights. ${ }^{31}$ 'Keep smiling through' is one of the lines of the Vera Lynn's 1939 song We'll Meet Again, one of the most popular and pervasive songs of the war. Alaistair Thompson's work on veterans of the First World War's Gallipoli campaign showed how popular culture representations (from the film Gallipoli) were drawn upon in the construction of the veterans' life narratives to conform to well-know images of masculinity. ${ }^{32}$ Whilst no direct agency can be proven 
between the song and the girls (it is also a line in 1929's Spread a Little Happiness, composed by Vivian Ellis for the musical $M r$ Cinders) it nevertheless suggests that the concepts signified by the phrases they employed were disseminated throughout public and national space and that these elements of popular culture were important in producing emotionally stable selves in the essays.

Enid Billany paraphrased another popular song when she wrote:

It's when I hear the aeroplanes that I am most frightened because we cannot do anything but just sit and wait, even if we sing... I hope we don't have any-more nights like those but if we do we are and we will keep our spirits till we hear the last all clear and our friends and relatives come home again. ${ }^{33}$

When they Sound the Last All Clear was another popular Vera Lynn song from 1940 concerning the return of loved ones after the war. Enid is thus associating the cessation of bombing with the end of the war. Unlike post-war accounts of the Blitz — which were written with the knowledge of certain victory — the essays here were written when further bombing was still a distinct possibility. When the essays were written Hull had not been bombed since early December 1941; however, the 33 raids Hull experienced in 1941 had not themselves commenced until February. Indeed, Hull had suffered 9 large raids between March and July 1941, which reached a peak in the catastrophic raids on the nights of the 8 and 9 May. ${ }^{34}$ The availability of a snappy, well-known, narrative tool appears to have given Enid a lexicon to articulate complex ideas of stoicism, composure and her desire for the bombing to end in a manner familiar to the potential readership.

The elements of popular culture deployed by the girls appear, as Benninghaus argues, as the 'outcome of an individually-distinct but decidedly non-arbitrary selection of ideas and norms. ${ }^{35}$ Examination of these essays indicates that the girls of Springburn Street School used particular elements of popular culture that appeared instantly accessible, both in the 
process of formulating a calm and balanced response to bombing, and in constructing themselves as wartime subjects possessed of civilian fortitude. The attempts to present an ultimately controlled and level-headed response, particular to fear and danger, thus represent attempts to maintain a degree of 'psychic comfort' through presenting favourable versions of themselves to an imagined audience. ${ }^{36}$

\section{Masculinities and Fatherhood}

The responses to the psychological effects of the raids were just one aspect of the way the girls narrated their experience. Whilst popular culture provided a useful way of subsuming a number of messages concerning the girls' internal, emotional reactions to the raids into a few words, the search for individual equanimity and the creation of a stable self within the discourse of wartime civilian service appears to also have extended to the favourable depiction of the family. One of the most striking devices deployed by the girls' is the articulation of perceived gender roles within the family, particularly the distinctions between the activities of fathers and mothers during and after air raids. Wartime ideas of gender roles appear as valuable models that facilitated the narration of the girls' families' contribution to the war effort. The essays thus suggests that stark gender divisions were not only exemplified in government expectations of civilian service, but were in fact central to the performance of the activities expected of the civilian.

The girls' words help to intervene in debates surrounding the construction of masculinity during the Second World War and the most prominent portrayal of masculine performance can be found in the girls' portrayal of fire watching. Sonya Rose argues that the dominant discourse concerning masculinity during the Second World War purposefully rejected the heroic masculinity of the Great War, focusing instead upon the reserved, selfdeprecating, cheerful courage of the ordinary man composed against a backdrop of temperate

British national identity. ${ }^{37}$ Summerfield and Raewyn Connell argue that although military 
service exemplified the predominant idea of hegemonic masculinity, various subordinated masculinities concerned with civilian service were constructed in relation to it. ${ }^{38}$ Indeed, the government made considerable efforts to mitigate any loss of masculine pride through a conflation of civilian service in the factory, ARP and Home Guard with active military service in poster campaigns. ${ }^{39}$ This prevalence of discourses concerning heroic masculinity partly explains the centrality of the father's fire watching activities to many of the essays. The activity of fire watching remains, in all but one of the essays, the exclusive preserve of the father, or male family members. In a rare case when the mother is involved, it is at the request of an older brother (presumably due to the absence of the father, who is away performing unspecified duties). ${ }^{40}$

A more detailed look at the representation of fire watching in local newspapers, prior to the writing of the essays, points to reasons why it may have been so prominent in the girls' depictions of male relatives. In 1941, in order to counter the threat of incendiaries during raids, campaigns were enacted by the government to emphasise the dangers of fire bombs. ${ }^{41}$ One element of the campaigns was the construction of fire fighting activities as a component in active wartime service in order to bolster the recruitment of fire watchers. Summerfield has shown that men who did not serve in the forces were often seen by women as less than 'real' men, but for those who were too ill, too old or worked in reserved occupations, the warden service or fire watching provided opportunities to be part of the war effort. ${ }^{42}$ However, the idea of the fire watcher as an exclusively masculine role was not entirely in line with the state's views. As the Hull Daily Mail (HDM) reported on 1 January 1941 , in one of four articles that day on fire watching, 'this is work in which every ordinary man and woman must co-operate' ${ }^{43}$ Furthermore, three days later it was eagerly reported that civilians had saved many buildings from fire bombs during air raids on Bristol, adding that a girl of 12 had been a 'Fire Bomb Heroine'. ${ }^{44}$ Almost every edition of the paper for the first 
five months of 1941 features references to fire watching- often in the form of an appeal for volunteers - which emphasise the importance of it as a part of civilians' contribution to the war effort. Indeed, on 8 May, mere hours before the most devastating raids on Hull, the paper lauded fire watchers as 'Our Civilian Heroes. ${ }^{45}$ Despite these attempts to place a nongendered emphasis on fire watching, Rose has demonstrated that women were often excluded,from activities like fire watching based on their perceived weakness and need to be protected. $^{46}$

This emphasis on fire watching as a vital contribution to the civilian war effort appears to have had a particular impact on the manner in which the girls of Springburn Street School presented it in their essays. For them, fire watching and associated activities appear to have been a bold and readily identifiable embodiment of heroic masculinity, most frequently used to present fathers. ${ }^{47}$ Alwyn Hornsby, for example, describes her father helping to carry furniture out of a neighbouring woman's burning house then extinguishing the flames with a stirrup pump before going back out fire watching. ${ }^{48}$ Not only is her father depicted fulfilling the role of fire watcher, but there is also a clear division between him putting out the fire and the seemingly helpless female neighbour. An idea of community action, illustrated in the $H D M$ call for 'all members of the community to counter the menace of incendiary bombs', is also evident in Winnie Stephen's account of a raid: 'Mrs Ingram got an incendiary bomb in her back bedroom and my father and brother put it out'. ${ }^{49}$ In both cases, it appears to have been important to the girls to foreground their fathers' contributions to the defence of the city and neighbourhood in the presentation of their masculinity.

Where the father is absent then an older brother frequently fills the masculine role in the girls' narratives. In Sylvia Palmer's account her brother extinguishes a nearby incendiary bomb with a bag of sand, since her father - mentioned earlier in the essay - is away fighting 
other fires. ${ }^{50}$ Similarly, Betty Wood recounts how, despite the presence of her mother, her older brother went out to extinguish an incendiary:

...there was a little bang and my brother said that he would have to go out as it was a firebomb and he would have to put it out. While he was putting it out a bomb dropped and blew him inside the shelter again. ${ }^{51}$

Here, Betty's brother not only takes responsibility for putting out the fire, but faces demonstrable danger in doing so, reinforcing his heroism. ${ }^{52}$ The desire to situate the heroism of the men of the family within narratives of dangerous events presents a facet of the girls' selves - displaying pride in the way in which their family contributed to the defence of Hull's community. It also emphasises the manner in which a readily accessible construction of masculinity — the males as the protectors of the family, home and community — was given greater visibility by the conditions of the war, potentially reinforcing the girls' stratification of gender identities.

The accounts of male relatives' duties during the bombing suggest a strongly spatial dimension to the girls' perceptions of gendered responsibilities. Men's responsibility in the narratives begins largely at the periphery of the home and they are responsible for the defence of the home and immediate neighbourhood from external threats. This spatialisation of performance echoes a dichotomy in men and women's feelings about the home and the outside world that was articulated in a Mass Observation (MO) report of $1943 .{ }^{53}$ The report found that men were far more likely to believe that the home was the 'pivot' from which the rest of their life stemmed. Conversely, women were more likely to see the home as the centre of their life. Enid Billany's account of her parents during an air raid epitomises the way the roles of father and mother were constructed in relation to each other and the home. She writes that '...my father was out firefighting then, he came back in with his arm burn[ed] and mother bandaged it up, then he went out again. ${ }^{54}$ The father, whilst conforming to 
conceptions of heroic masculinity through his injury is also portrayed as returning from the fray to the home, the site of comfort and safety. ${ }^{55}$ In performing the role of the nurse, Enid's mother herself conforms to a model of nationalistic duty and a feminine wartime role exemplified in nursing, emphasised by Anne Summers. ${ }^{56}$ Yet she is also depicted as waiting at home with the children ready to minister to the hero's needs. Enid's decision to make it central to her account of the bombing suggests that she felt this was a positive and important episode in the presentation of her family's contribution to the war effort.

What can be detected in the mapping of the experiences of the Blitz onto the home is an echo of Pierre Bourdieu's description of the gendered differences made material in the homes of the Berber peoples of northern Africa. Bourdieu describes how, for men, the house is a place from which one sallies forth to engage with the outside world. The masculine relationship with the home is reinforced by both the spatial arrangement of the dwelling and the practices of gender associated with it. ${ }^{57}$ The girls studied here narrate their fathers into the stories, even when their fire watching activities are peripheral to the girls' own experience.

The girls' narratives conform to wartime discourses of civilian service and place their families at the heart of emerging narratives of civilian fortitude. In order to do this the girls reproduced a recognisable discursive framework that used a well-known and easily identifiable role (the fire watcher) to demonstrate the usefulness and heroism of their families. The girls, then, were not only selecting discursive elements as Benninghaus argues, they were going further. They were harnessing their writing to subscribe to an idea through use of a kind of 'cultural shorthand', which articulated in just a few words their ready subscription to established models of masculinity, civilian fortitude and patriotic duty.

Representations of masculinity through wartime service, though, are not limited to fathers and brothers and extend beyond the family, albeit occupying a somewhat different position in the girls' narratives. When other men intrude into the girls' stories they are usually wardens, 
soldiers or policemen. In all cases they are figures of masculine authority instructing civilians what to do, evacuating them to a local rest centre and, in one case, digging them out of a ruined shelter. ${ }^{58}$ Wardens, in particular, are regularly presented as figures of both authority and expertise. In Rita Drysdale's account, whilst her family takes shelter, the wardens enter and instruct them to take cover. ${ }^{59}$ This position of authority does not just end with those given positions of manifest power. In Edna Fewster's recollection we see that authority is afforded to men in general: 'every time a bomb came down I screamed and cried I was very frightened. All the men shouted; "duck there's one coming down" and we all bent down on our hands and knees. ${ }^{60}$ Not only does Edna explicitly equate the voice of authority with the men in the shelter, she also juxtaposes it with her own fear.

The girls of Springburn Street School, via their experience of air raids, were able to assemble a workable model of masculinity in accordance with the discourses of the war. This process potentially reinforced the girls' sense of gender roles, especially when comparison is made with their treatment of their mothers, who rarely perform the tasks expected of the fire watchers. The men in the stories are authoritative and quietly heroic characters fulfilling a crucial role in the defence of the city. The girls' narratives situate these men within apparently rigid definitions of gender performance, which cast the male as defender of the home and its locality against aggression.

\section{Femininity}

If masculinity is primarily identified with authority and heroism within the essays then the roles of females are presented rather differently. The existence of distinct feminine narratives of the war has been emphasised by many writers, particularly Penny Summerfield, Helen Jones and Sonya Rose, who all challenge post-war assumptions about the emancipatory benefits of the war for women. ${ }^{61}$ Phil Goodman has pointed out that the outward nature of patriotic femininity entailed the state identifying and promoting categories of women as 
wives, mothers, temporary workers or sex symbols. ${ }^{62}$ Summerfield, dealing with individual memories, demonstrates a fractured idea of wartime femininity, with no unified central construct either at the time, or in the personal testimonies of her respondents. ${ }^{63}$ However, the girls of Springburn Street School do demonstrate a high degree of uniformity and a clear cut vision of wartime gender both for themselves and their mothers, which are only further emphasised by the comparison with the presentation of males.

It is not easy to be sure why such a difference exists; however, I want to suggest that the dominance of a discourse which constructed the mother's primary role as a facet of civilian service, suggested by Summerfield, was at work. ${ }^{64}$ The representation of a mother's role during the war, in comparison to other models of the feminine contribution, appears to have been primarily fixed and related to preserving the home whilst raising children. ${ }^{65}$ As Summerfield has argued:

the great bulk of wartime domestic work was thrown back to the private sphere of a woman's own resources and those of her family, friends and neighbourhood, albeit parcelled in the rhetoric of the war effort. ${ }^{66}$

Conversely, teenage girls and young women were presented as a mobile auxiliary work force. ${ }^{67}$ The girls of Springburn Street School, however, represent a group in the formative stages of acquiring their roles as adult women and this gives them a rather mixed set of responsibilities. In the girls' accounts they almost exclusively position themselves in relation to their mothers, suggesting a growing sense of their own gender identity and girlhood, which the demands of wartime allowed them to qualify.

Enid Billany demonstrates how the routine of helping mother during raids was fundamental to both the girls' construction of themselves as useful members of family, and the war effort. 'I have a certain job when we hear the sirens at night... [I] carry the gasmasks and mother's bag to the shelter while she carries little brother. ${ }^{68}$ Similarly, Betty Start 
recounts: 'When the sirens blow I get ready and get my brothers ready and then I get my mother's policies'. ${ }^{69}$ These planned actions show how important assisting their mother was for the girls' own sense of personal worth, especially against a national discourse which stressed collective steadfastness. The habit of taking valuables, insurance policies, family photographs and other essential paperwork, whilst practical under the circumstances, shows how Enid's mother was responsible for preserving as much of the home and the family's life should the worst occur. This activity does not seem to have been an idiosyncrasy of Enid's mother alone, as can be seen in accounts made some years after the war. Arthur Dales, a bicycle messenger during the blitz on Hull, recalls that his mother would fill a small suitcase with 'important documents such as ration cards and insurance policies' and take it to the shelter. ${ }^{70}$ Patricia McGowan, writing in 2004, also remembered that her mother:

...always had, under her arm, the attaché case in which our life insurance policies were housed and also documents such as Birth Certificates and Death Certificates, old photographs and personal letters, in fact anything that qualified as being important and precious. $^{71}$

Clare Cooper Marcus has commented that the occupants' possessions are at least as important as the building itself in constructing a sense of place and home and in this way the house is a mirror of self. ${ }^{72}$ Crucial to the role of women during the war, then, was the ability to preserve or restore the physical elements of the home's interior - be they photographs, policies or valuables. This notion of the mother as the maintainer of internal order then explains why the cleaning of bomb damaged homes is an activity which, in the accounts viewed here, was crucial to feminine performance. Florence Atkinson, for example, recalls staying up all night to assist her mother cleaning up the chimney soot and smashed ornaments in their bombed house. ${ }^{73}$ Margret Bennett goes even further when her house suffers minor damage: 'When we got into the house there wasn't half a mess. I started to tidy up and then I 
lighted [sic] the fire and made my mother and the two other children a nice hot cup of tea. ${ }^{74}$ Whilst she assists with domestic activities, Margret also constructs a narrative in which she becomes responsible for everything, despite there being no indication that her mother was in any way incapacitated. It is, of course, possible that these were Margret's jobs on a daily basis, and she may also have inflated her own importance to events. However, what is important is that she chooses to make her own role crucial to the restitution of the damaged home, and foregrounds these as part of her response to the events she has witnessed. Margret and Florence's notions of what their own performance of gender should be appear intrinsically tied up with being apprenticed to their mothers or stepping in to perform tasks that blur the boundaries between the mother and child.

If the role of the male relatives appears to be as defenders against aggression towards the home, then the role of the females is largely as the guardians of the order and practice of domestic life. The post-war memories of Ken Long, then a young boy in London, are useful for demonstrating how the intersection of the house with civil defence measures could breach the home's perceived boundaries and reveal the role he attributed to his mother:

Roof spaces and attics were cleared out as an anti-incendiary measure. When we had our first incendiary bomb through the roof of our house the firemen rushed upstairs with hoses etc. to put out the fire before it spread too far. My very house-proud mother was most upset because they didn't wipe their feet first. ${ }^{75}$

Whilst Long, with the distance of 60 years and the retrospective knowledge of victory, casts his mother's disquiet at the intrusion in a light-hearted tone, his recollection demonstrates the way her role in maintaining the internal domestic space was threatened by the measures necessary for civil defence. Similarly, in the MO report Women and War it was reported that women initially found the blackout more of a problem than men, due to their responsibility for maintaining the interior of the home. ${ }^{76}$ As another MO survey would suggest, women 
might be more susceptible to modifications to the home itself, since their experience of home centred on the dwelling than the outside. ${ }^{77}$

The role of the girls as apprentices to their mothers in the run up to womanhood appears to reflect their own notions of what this particular phase of their girlhood meant during the war. Betty Start's account not only shows her helping her mother, but also hints that girls of a certain age would begin to assist in child care, even for non-family members. During a night in the shelter Florence Atkinson relates the following:

I was glad that I could do something to help, for there was a lady who came into our shelter who was very frightened. She had a little child of one and a half years. The lady was trembling, I took the little baby, and every time a bomb came down I threw a pillow over myself and the little girl, who was called Sheila. She kept crying but at last I hushed her to sleep. ${ }^{78}$

Here, Florence depicts herself as a useful component in the wartime community by assisting a distressed stranger, whilst also emphasising her own maternal skills. Her willingness to help is especially stark when compared to the nameless lady whose fear has robbed her of these qualities. The idea that girls aged between ten and twelve would be learning to assist the family in working-class homes in 1942 is not revolutionary, yet the pride taken in their ability to perform like a mother reveals a perception of useful wartime behaviour which places these gendered activities at the core of constructing a useful wartime self. Rita Drysdale's account even goes as far as to blur the distinction between herself and her mother's areas of responsibility: 'When the sirens went we rushed out with the children. We [Rita and her mother] had five children to look after and I was the eldest...I got all of our children under the bed [my emphasis] ${ }^{79}$ Rita articulates a consciousness of the expectations of her as a young woman (she is 12 years old) emphasised by the stress of the Blitz, yet her role is fluid - she is both one of the children and simultaneously one of their carers. 
What is important about the girls' interactions with their mothers is that they hint at how activities that would perhaps have been expected of the girls in peacetime were easily recast as part of the war effort. Thus, assisting mother, childcare and cleaning - all tasks which pre-teen girls might be expected to carry out - appear in the essays as ways of articulating the girls' conformance to notions of civilian contribution to the war. Only Hilda Chalk, who helped her father 'make sure that no firebombs hit the house', and Audrey Leaman, who left the shelter to see if there was any bomb damage to the home, deviate from performances which cast females as the maintainer of the home. ${ }^{80}$ These exceptions though are unsurprising, since no unified idea of femininity is likely to have existed for all the girls at the same time. Nevertheless, the clarity of the girls' delineation of gendered roles and their willingness to harness them suggests problems with extending to girls of this age Goodman's assertion that:

The war years demonstrate tensions between discourses constructing gender relations...appropriate feminine behaviour became increasingly problematised as the dichotomous divisions constructing and locating gender relations were no longer as clearly defined or maintained in the experience of wartime conditions. ${ }^{81}$ For the girls of Springburn Street School the gendered roles which they ascribe to the people around them, and with which they constitute their own ideas of useful contribution to the war, are largely clear-cut and suggest little tension. Perhaps more importantly though the prevalence of easily identifiable gender roles appears to have been useful to the girls in the process of articulating their contribution to the war effort.

\section{Conclusion}

In their essays the girls of Springburn School give us a snapshot from a single day in 1942 of the manner in which a group of girls, on the cusp of adolescence, articulated and utilised dominant narratives to present their experience of bombing. In writing down their 
experiences the girls recreated the urban landscape of a provincial city at war, articulated notions of gender and the home and demonstrated the impact of wartime expectations concerning civilian fortitude on the presentation of themselves and their families.

The preceding analysis of the essays suggests that by deploying a methodological framework that views the construction of narratives as the outcome of assembling various accessible discursive elements, children's life writing may be analysed on a par with adults' writing. The usefulness of the essays considered here lies not in the utilisation of the girls as witnesses, since such an approach that would raise questions about children of ten to twelve's ability to understand and reproduce events with 'factual' accuracy. Instead, the value of children's accounts lies in the way that their work reflects the discursive environment of wartime Britain. Viewing the essays as acts of composure allows us to further understand the power of messages produced by the state to create expectations of wartime civilian service. The evidence indicates that the girls sought psychic composure through the creation of conformative selves in the essays. Thus the essays illustrate attempts to project a favourable image within a pervasive discourse that placed heavy stress on the outward signs of good morale as a component of civilians' patriotic duties. Furthermore, the frequency of references to popular culture as a way of articulating stoicism and as a means of mitigating incidences of fear in the essays suggest that easily understood, widely disseminated elements of wartime culture — such as lines from songs — provided the girls with a lexicon through which they might negotiate and present balanced selves.

The girls' attempts to achieve equanimity in their narratives are not limited to their own internal emotional selves. Through the presentation of their families' contribution to the defence of home, neighbourhood and thus the wider city the girls show how important distinct, binary concepts of gender roles were to themselves and to state models of civilian service. The consistency and uniformity of the manner in which the girls delineate gender 
roles implies a conservatism that was reinforced by the subjectivities of wartime, but also evidences the way the state sought to produce responsible, civilian defenders in urban areas by encoding gendered roles in the activities necessary for the defence of the home. The role of the mother as the maintainer of order in the home - a role which the girls appear to have assisted with - and the construction of fathers and male relatives as fire watchers defending the home from external threats, suggest how pervasive state narratives of civilian service were. Whilst the essays thus narrate and communicate the girls' adherence to societally stratified, binary concepts of gender, their creation also forms part of the performance of gender itself. The essays thus represent what Judith Butler has called a 'tacit collective agreement to perform, produce, and sustain discrete and polar genders as cultural fictions'. ${ }^{82}$ Kristine Miller had argued that bombing challenged traditional notions of the home and that 'convergence of the home front and the front line posed an ideological challenge to traditional gender roles. ${ }^{83}$ However, the evidence presented here suggests that the experience of bombing was instrumental in reinforcing pre-existing gender roles. It is difficult to speculate whether the experience of war may have altered or emphasised the girls' conception of gender roles, since we have no comparative writing from the pre-war period. What the essays do indicate is that the war offered opportunities for the girls to construct their ideas of appropriate gender roles against the expectations of civilian contribution to the war effort. 
${ }^{1}$ Hull History Centre (HHC), Kingston upon Hull, Children's Recollections of the Blitz, L9.7085, L DEX/24, 9 February 1942. The essays were gifted to the archive in November 2003.

${ }^{2}$ K.J. Allison (ed.), A History of the County of York East Riding, Vol. 1: The City of Kingston Upon Hull (Oxford: Oxford University Press, 1969), 372.

${ }^{3}$ Records held at Hull History Centre (HHC, CTAY, Various Records of the Air Raids, 21 June1940 - 18 March 1945) indicate only 65 raids that caused damage; however, Tom Geraghty, North East Coast Town: Ordeal \& Triumph: The Story of Kingston-Upon-Hull in the 1939-1945 Great War (Hull, 2002) and Philip Greystone, The Blitz on Hull (1940-45) (York, 1991) give figures of 72 using newspaper reports alongside the records of local government.

${ }^{4}$ Both Margaret Bennett (HHC, L DEX 24/2) and Irene Doherty's (HHC, L DEX 24/7) accounts mention being moved from another school.

${ }^{5}$ Penny Summerfield, 'Culture and Composure: Creating Narratives of the Gendered Self in Oral History Interviews', Cultural and Social History, 1:1 (2004), 65-93; Graham Dawson, Soldier Heroes: British Adventure, Empire and the Imagining of Masculinities (London: Routledge, 1994).

${ }^{6}$ Juliet Gardiner, The Children's War: The Second World War through the Eyes of the Children of Britain (London; Portrait, 2005); Gabriel Moshenka, 'A Hard Rain : Children's Shrapnel Collections in the Second World War', Journal of Material Culture, 13:1 (2008), 107-125; William M. Tuttle, Daddy's Gone to War: The Second World War in the Lives of America's Children (Oxford: Oxford University Press, 1993); Emmy E. Werner, Through the Eyes of Innocents: Children Witness World War II (Oxford: Westview Press, 2000).

${ }^{7}$ Susan Isaacs, The Cambridge Evacuation Survey: A Wartime Study in Social Welfare and Education (London: Methuen \& Co. Ltd, 1941); John Welshman, Churchill's Children: the Evacuee Experience in Wartime Britain (Oxford: Oxford University Press, 2010).

${ }^{8}$ Amy Helen Bell, London Was Ours: Diaries and Memoirs of the London Blitz (London: I.B. Tauris, 2008);

Jean R. Freedman, Whistling in the Dark: Memory and Culture in Wartime London (Kentucky: University Press of Kentucky, 1999); Ken Hewitt, 'When the Great Planes Came and Made Ashes of Our City...: Towards an Oral Geography of the Disasters of War', Antipode 26:1 (1994), 1-34.

${ }^{9}$ Bell, London Was Ours, 132-133. 
${ }^{10}$ Penny Tinkler, Constructing Girlhood: Popular Magazines for Girls Growing up in England, 1920-1950

(London: Taylor \& Francis, 1995); Valerie Walkerdine, Daddy's Girl: Young Girls and Popular Culture

(London: Harvard University Press, 1997).

${ }^{11}$ Gaston Bachelard, The Poetics of Space (Boston: Beacon Press, 1992).

${ }^{12}$ Penny Summerfield, Reconstructing Women's Wartime Lives: Discourse and Subjectivity in Oral Histories of the Second World War (Manchester: Manchester University Press, 1998), 185; Penny Summerfield and Corinna Peniston-Bird, Contesting Home Defence: Men, Women and the Home Guard in the Second World War (Manchester: Manchester University Press, 2007), 11.

${ }^{13}$ Claire Langhamer, 'The Meanings of Home in Postwar Britain', Journal of Contemporary History 40:2 (2005), 341-362; Kristine A Miller, 'Even a Shelter's Not Safe: The Blitz on Homes in Elizabeth Bowen's Wartime Writing', Twentieth Century Literature 45:2 (1999), 138-158 [140].

${ }^{14}$ Pam Alldred and Erica Burman, 'Analysing Children's Accounts Using Discourse Analysis', in Sheila Greene and Diane Hogan (eds.), Researching Children's Experience (London: SAGE Publications, 2005), 175-198 [191].

${ }^{15}$ Christina Benninghaus, 'Mother's Toil and Daughter's Leisure:Working-class Girls and Time in 1920s Germany', History Workshop Journal 50 (2000), 45-72.

${ }^{16}$ Carolyn Steedman, The Tidy House: Little Girls Writing (London: Virago Press Ltd, 1982), 91-92.

${ }^{17}$ Benninghaus, 'Mother's Toil and Daughter's Leisure'; Steedman, The Tidy House.

${ }^{18}$ Teun A. van Dijk, 'Critical Discourse Analysis', in Deborah Schiffrin, Deborah Tannen, and Heidi Ehernberger Hamilton (eds.), The Handbook of Discourse Analysis, (Oxford: Oxford University Press, 2001), 352-371; J.T. Irvine, 'Strategies of Status Manipulation in the Wolof Greeting', in Richard Bauman and Joel Sherzer (eds.), Explorations in the Ethnography of Speaking (London: Blackwell, 1974), 167-191; V. K. Bhatia, Worlds of Written Discourse (London: Continuum, 2004).

${ }^{19}$ Max Hastings, Bomber Command (London: Pan, 1999), 159.

${ }^{20}$ HHC, Nancy Nunn, L DEX 24/20.

${ }^{21}$ HHC, Hilda Chalk, LDEX 24/6.

${ }^{22}$ Summerfield, 'Culture and Composure'; Dawson, Soldier Heroes.

${ }^{23}$ Dawson, Soldier Heroes, p.23. 
${ }^{24}$ Brad Beaven and John Griffiths, 'The Blitz, Civilian Morale and the City: Mass-Observation and Workingclass Culture in Britain, 1940-41', Urban History 26:1 (1999), 71-88; Brad Beaven and David Thoms, 'The Blitz and Civilian Morale in Three Northern Cities', Northern History 32 (1996), 195-203; Robert Mackay, Half the Battle: Civilian Morale in Britain During the Second World War (Manchester: Manchester Unviversity Press, 2003). Arthur Marwick, The Home Front, the British and the Second World War (London: Thames \& Hudson Ltd, 1976), 69 -72.

${ }^{25}$ Mackay, Half the Battle, 2-3.

${ }^{26}$ Winifred Stubbins, HHC, L DEX 24/28.

${ }^{27}$ Sheila Stothard, HHC, L DEX/24/27.

${ }^{28}$ Sheila Stothard, HHC, L DEX/24/27.

${ }^{29}$ Edward Glover, 'Notes On the Psychological Effects of War Conditions on the Civilian Population (III. the 'Blitz' - 1940-1)', International Journal of Psycho-Analysis, 23 (1942), 29-37, quoted in: Lyndsey Stonebridge

'Anxiety at a Time of Crisis' History Workshop Journal, 45 (1998), 171-182 [172].

${ }^{30}$ Gardiner, The Blitz, 184.

${ }^{31}$ Hilda Chalk, HHC, L DEX/24/6; Nancy Nunn, HHC, L DEX/24/20.

${ }^{32}$ Alistair Thomson, Anzac Memories: Living with the Legend (Oxford: Oxford University Press, 1994)

${ }^{33}$ Enid Billany, HHC, L DEX/24/2.

${ }^{34}$ HHC, C TAY, Various Records of Air Raids, 21 June 1940 - 18 March 1945.

${ }^{35}$ Benninghaus, 'Mother's Toil and Daughter's Leisure', 48.

${ }^{36}$ Summerfield, 'Culture and Composure', 69.

${ }^{37}$ Sonya O. Rose, 'Temperate Heroes: Concepts of Masculinity in Second World war Britain', in Stefan Dudink, Karen Hagemann and John Tosh (eds.), Masculinities in Poltics and War: Gendering Modern History (Manchester: Manchester Universtiy Press, 2007), 177-198.

${ }^{38}$ Raewyn Connell, Gender and Power: Society, the Person and Sexual Politics (Cambridge: Cambridge University Press, 1987); Summerfield, Reconstructing Women's Wartime Lives, 118-124.

${ }^{39}$ See John D. Cantwell, Images of War: British Poster 1939-1945 (London: Public Record Office, 1989), plates $44,47-49$.

${ }^{40}$ HHC, Mary Oxley, L DEX/24/21. 
${ }^{41}$ See the 'Firebomb Fritz' posters displaying a series of cartoons produced between 1941 and 1942 to encourage fire watching contained in The National Archives: Public Record Office, Kew, INF3/1362, $1421,1423 \& 1425$.

${ }^{42}$ Summerfield, Reconstructing Women's Wartime Lives.

${ }^{43}$ Hull Daily Mail (HDM), 1 Jan 1941, 1.

${ }^{44}$ HDM 4 Jan 1941, $1-4$.

${ }^{45}$ HDM 8 May 1941, 2.

${ }^{46}$ Sonya O. Rose, Which Peoples War? National Identity and Citizenship in Wartime Britain (Oxford: Oxford University Press, 2004), particularly 111- 115.

${ }^{47}$ Fathers do not appear in all of the essays and the reasons for this are not clear. Those absent may have been dead, separated from the family, on active service or merchant seamen who were away for long periods of time. What is worth noting is that none of the girls describe the reasons their fathers do not appear in their accounts.

${ }^{48}$ HHC, Alwyn Hornsby, L DEX 24/14.

${ }^{49}$ HDM 2 Jan 1941, 5 and HHC, Winnie Stephen, L DEX 24/26.

${ }^{50}$ HHC, Sylvia Palmer, L DEX/24/22.

${ }^{51}$ HHC, Betty Wood, L DEX/24/29.

${ }^{52}$ HHC, Betty Wood, L DEX/24/29.

${ }^{53}$ Mass Observation Archive (MOA) File Report (FR) 1616, 3 March 1943 p.1 \& 9-11.

${ }^{54}$ HHC, Enid Billany L DEX/24/3.

${ }^{55}$ Peter Lehman, Running Scared: Masculinity and the Representation of the Male Body (Philadelphia: Wayne State University Press, 1993); Tamara Neal, The Wounded Hero: Non-Fatal Injury in Homer's Iliad (Bern: Peter Lang, 2006); Christine F. Salazar, The Treatment of War Wounds in Graeco-Roman Antiquity (Boston: Brill, 2000) , 74-76; Kenneth Hodges. 'Wounded Masculinity: Injury and Gender in Sir Thomas Malory's Le Morte D'Arthur', Studies in Philology 106:1 (2009), 14-31.

${ }^{56}$ Anne Summers, Angels and Citizens: British Women as Military Nurses 1854-1914 (London: Routledge, 1988).

${ }^{57}$ Bourdieu, 'The Berber House', 134-136.

${ }^{58}$ HHC, Ellie Smith, L DEX/24/23.

${ }^{59}$ HHC, Rita Drysdale, L DEX/24/9. 
${ }^{60}$ HHC, Edna Fewster, L DEX24/12.

${ }^{61}$ Helen Jones, British Civilians in the Front Line: Air Raids, Productivity and Wartime Culture, 1939-45,

(Manchester: Manchester University Press, 2006); Rose, Which Peoples War?; Summerfield, Reconstructing Women's Wartime Lives.

${ }^{62}$ Phil Goodman, 'Patriotic Femininity: Women's Morals and Men's Morale During the Second World War', Gender Studies, 10:2 (1998), 278-293 [287].

${ }^{63}$ Summerfield, Reconstructing Women's Wartime Lives.

${ }^{64}$ Summerfield, Reconstructing Women's Wartime Lives, 185.

${ }^{65}$ Women with children under 14 were exempt from any kind of service, see: Margaret Allen, 'The Domestic Ideal and the Mobilization of Womanpower in World War II', Women's Studies International Forum, 6:4 (1983), 401-412.

${ }^{66}$ Penny Summerfield, Women Workers in the Second World War: Production and Patriarchy in Conflict (London: Routledge, 1984), 185.

${ }^{67}$ Goodman, 'Patriotic Femininity’ 278-293.

${ }^{68} \mathrm{HHC}$, Enid Billany, L DEX/24/3.

${ }^{69} \mathrm{HHC}$, Betty Start, L DEX/24/24.

${ }^{70}$ IWM(L) SA, Arthur Dales, ref:14595, 4 October 1994

${ }^{71}$ BBC PWA, Patricia McGowan ‘An Air Raid Incident from World War Two’, ID:a2869770, 27 July 2004, online source: http://www.bbc.co.uk/history/ww2peopleswar/stories/70/a2869770.shtml, accessed 25 October 2012.

${ }^{72}$ Clare Cooper Marcus, House as a Mirror of Self: Exploring the Deeper Meaning of Home (Berkeley: Conari Press, 1995), 287.

${ }^{73}$ HHC, Florence Atkinson, L DEX/24/21.

${ }^{74}$ HHC, Margret Bennett, L DEX/24/2.

${ }^{75}$ BBC PWA, Ken Long, 'Growing Up in London 1939-1945', ID:a2065402 20 November 2003, online source http://www.bbc.co.uk/history/ww2peopleswar/stories/02/a2065402.shtml, accessed 28 October 2012.

${ }^{76}$ MOA FR 290, Women in Wartime, 23 July 1940, 6\&7.

${ }^{77}$ MOA FR 1616, Some Psychological Factors in Home Building, 3 March 1943, 2.

${ }^{78}$ HHC, Florence Atkinson, L DEX/24/1. 
${ }^{79}$ HHC, Rita Drysdale, L DEX/24/9.

${ }^{80}$ HHC, Hilda Chalk L DEX/24/6 \& Audrey Leaman, L DEX/24/18.

${ }^{81}$ Goodman, 'Patriotic Femininity', 287.

${ }^{82}$ Judith Butler, 'Performative Acts and Gender Constitution: An Essay in Phenomenology and Feminist

Theory', in Sue-Ellen Case (ed.) Performing Feminisms, Feminist Critical Theory and Theatre, (Baltimore:

Johns Hopkins University Press, 1990), 273.

${ }^{83}$ Miller, 'Even a Shelter's Not Safe', 140. 